\title{
KEARIFAN LOKAL MASYARAKAT DALAM MENGELOLA SUMBER MATA AIR DI DESA CAONG KECAMATAN MEMPAWAH HULU KABUPATEN LANDAK
}

\author{
(Local Community in Managing Water Sources in Caong Village Mempawah Hulu District \\ Landak Regency)
}

\author{
Frederikus Iren, Sofyan Zainal, Emi Roslinda \\ Fakultas Kehutanan Universitas Tanjungpura Pontianak. J1. Daya Nasional Pontianak 78124 \\ Email : irenfrederikus123@gmail.com
}

\begin{abstract}
Local wisdom is the value or attitude of local people's life in interacting with the environment where they live in a wise life. The village of Caong has local wisdom in the management of water sources. This research aims to assess the local wisdom of the community in managing water sources and analyzing the relationship of social perception in applying local wisdom from each factor such as customary law, trust, and Knowledge. The method used in this research is the survey method with an interview technique with a questionnaire, and the respondents taking purposive random sampling. Analysis of data using descriptive analysis with Chi-Square test analysis and inferential analysis using the non-parametric analysis correlation of Kendall Tau. The number of respondents used in this study was 85 respondents. Local wisdom conducted by the community of Caong village in managing the source of the water, namely the activities of managing the springs and traditions and rituals of society: the activities of administering the water source (making dams (Pagunkg), and team cleaning springs, planting Trees, repair facilities, and create drains). Local wisdom in the form of community traditions and rituals on the management of the source of water, are customary law, norms, special rules, and traditional rituals of worship in the spring water (nyangahan't ka ulu ai). Public perception of water resources management tends to be positive, high customary law, high level of community confidence, and high level of community knowledge. There is a significant link between public perception on the management of the water source of Caong village with customary law, trust, and knowledge.
\end{abstract}

Keywords: Caong village, local wisdom, management, water resources.

\section{PENDAHULUAN}

Kearifan lokal merupakan tata nilai atau prilaku hidup masyarakat lokal dalam berinteraksi dengan lingkungan tempatnya hidup secara arif (Akhmar dan Syarifudin, 2007). Karakteristik kearifan lokal pada setiap daerah berbeda-beda. Kearifan lokal pada komunitas tertentu dapat ditemukan bentuk pengelolaan sumber daya alam sebagai tata pengaturan lokal yang muncul sejak masa lalu melalui sejarah dan adaptasi yang lama (Oktaviani dan Dharmawan, 2010). Secara empiris kearifan lokal tersebut telah berhasil dalam pengelolaan sumber daya alam, yaitu mencegah kerusakan fungsi lingkungan, baik tanah/lahan, hutan, maupun air. Sumberdaya air merupakan salah satu unsur yang sangat penting untuk keberlanjutan kehidupan makhluk hidup terutama manusia. Keberadaan air dapat berperan multiguna, dapat digunakan sebagai air minum dan MCK 
(mandi, cuci, kakus), mengairi lahan pertanian, religius (mendukung pelaksanaan ibadah) dan ekonomi. Pengelolaan terhadap sumber daya air diperlukan agar keberadaannya tetap bermanfaat dan berkelanjutan untuk kepentingan jangka Panjang. Buwono $d k k$ (2017), pengelolaan sumber daya air yang berkelanjutan bertujuan untuk menjaga ketersediaan untuk saat ini dan masa yang akan datang serta terjaminnya ketersediaan untuk masa yang akan datang.

Sumber mata air yang berada di Desa Caong Kecamatan Mempawah Hulu Kabupaten Landak ini merupakan salah satu sumberdaya alam yang sangat penting bagi kehidupan masyarakat Desa Caong. Masyarakat memanfaatkan sumber mata air ini sudah sejak zaman dahulu, sumber mata air tersebut masyarakat manfaatkan untuk memenuhi kebutuhan hidup sehari-hari seperti keperluan rumah tangga, bidang pertanian, budidaya ikan, dan kebutuhan lainnya. Akhir-akhir ini kondisi sumber mata air yang masyarakat manfaatkan mulai mengalami penurunan dibeberapa tempat ketersediaan air mulai berkurang bahkan ada yang mengalami pengeringan. Hal ini disebabkan oleh beberapa faktor yaitu kurangnya kesadaran masyarakat dalam menjaga lingkungan sumber mata air seperti halnya kegiatan pertanian yang mengabaikan kelestarian lingkungan, perubahan fungsi lahan menjadi perkebunan dan pengundulan hutan. Upaya untuk mengelola dan menjaga sumber mata air melalui kearifan lokal masyarakat diperlukan supaya keberadaan sumber mata air dapat dipertahankan serta kebutuhan masyarakat terhadap air bisa terpenuhi, selain itu kearifan lokal juga ikut berperan dalam menjaga keberadaan dan kelestarian sumber mata air yang ada di Desa Caong melalui pengetahuan lokal dan tradisi yang masyarakat miliki dalam mengelola sumber mata air dengan tetap memperhatikan kelestarian lingkungan sehingga manfaatnya dapat dirasakan baik untuk saat ini dan untuk masa mendatang. Penelitian ini sangat penting dilakukan supaya masyarakat tetap menjaga dan melestarikan nilai budaya kearifan lokal mereka khususnya dalam mengelola sumber daya air dan bisa sebagai acuan pengelolaan untuk masa yang akan datang tanpa meninggalkan keberadaan kearifan lokal masyarakat. Penelitian ini bertujuan untuk mengkaji bentuk kearifan lokal masyarakat terhadap pengelolaan sumber mata air dan menganalisis hubungan persepsi masyarakat dalam menerapkan kearifan lokal dari masing-masing faktor seperti; hukum adat, kepercayaan, dan pengetahuan.

\section{METODE PENELITIAN}

Penelitian ini dilaksanakan di Desa Caong Kecamatan Mempawah Hulu Kabupaten Landak. Pengumpulan data dilakukan dalam waktu 3 minggu di lapangan, dimulai tanggal 6 Juli- 27 Juli 2019. Penelitian ini menggunakan metode survey yang bersifat deskriptif dan asosiatif dengan teknik wawancara 
dan menggunakan alat bantu kuesioner berupa formulir daftar pertanyaan yang diajukan kepada sejumlah responden. Metode pengambilan sampel penelitian dengan menggunakan metode Purposive Random Sampling. Penentuan besarnya ukuran sampel dalam penelitian ini menggunakan rumus Slovin, Khadapi (2015) sebagai berikut:

$$
\mathrm{n}=\frac{N i}{1+\sum N i . e^{2}}
$$

Keterangan:

ni = Jumlah sampel responden ke $\mathrm{i}$

$\mathrm{Ni}=$ Jumlah populasi responden $\mathrm{ke} \mathrm{i}$

$\mathrm{i}=1,2,3,4$

$\mathrm{e}=$ Batas toleransi kesalahan (Persen

Kesalahan)

Kriteria masyarakat yang dijadikan responden secara purposive random sampling adalah sebagai berikut : (a) Kepala keluarga (b) Responden berdomisili dan sudah menetap lebih dari 5 tahun (c) Masyarakat yang menggunakan sumber mata air (d) Sehat jasmani dan rohani. Jumlah populasi yang ada di Desa Caong yaitu sebanyak 467 Kepala Keluarga yang terdiri dari lima Dusun, yaitu Dusun Kayuara, Pelanjau, Pakan, Keranji, dan Caong. Berdasarkan perhitungan menggunakan rumus slovin didapat responden 85 kepala keluarga. Data yang dikumpulkan dalam penelitian ini meliputi; (1) Data primer yaitu data mengenai bentuk kearifan lokal masyarakat terhadap pengelolaan sumber mata air dan persepsi masyarakat yang akan dihubungkan dengan faktor hukum adat, tingkat kepercayaan, dan tingkat pengetahuan, (2) Data sekunder adalah data yang bersifat penunjang yaitu data yang diperoleh dari literatur, serta data-data yang diperoleh dari kantor atau lainnya. Data ini meliputi peta lokasi, catatan, rekaman dan keadaan umum lokasi penelitian. Data tersebut ditabulasikan dan kemudian dianalisis. Analisis deskriptif variabel kearifan lokal menggunakan Chi Square dengan rumus sebagai berikut:

$$
x^{2}=\sum_{i=1}^{k} \frac{\left(f_{0}-f_{h}\right)}{f_{h}}
$$

Dimana:

$\mathrm{x}^{2}=$ Chi - kuadrat

$\mathrm{f}_{0}=$ Frekuensi yang diobservasi

$\mathrm{f}_{\mathrm{h}}=$ Frekuensi yang diharapkan

Untuk mengetahui hubungan variabel terikat dan variabel bebas dilakukan menggunakan Uji Korelasi Kendall Tau dengan rumus sebagai berikut (Pryatno, 2010) :

$$
r=\frac{\frac{\sum A-\sum B}{N(N-1)}}{2}
$$

Keterangan :

r : Koefisien Korelasi Kendall Tau

A : Jumlah Rangkaian Atas

B : Jumlah Rangkaian Bawah

N : Jumlah Gagasan Sampel

\section{HASIL DAN PEMBAHASAN}

\section{Sumber Mata Air Di Desa Caong}

Desa Caong memiliki lima sumber mata air sesuai yang ditemukan di lapangan saat ini, yaitu sumber mata air Sanepo, Batu Maet Ai, Pate, Arong 
Sano, dan Canga. Sumber-sumber mata air ini terdapat di lima Dusun yang berbeda yaitu di Dusun Kayuara, Dusun Pelanjau, Dusun Pakan, Dusun Keranji dan Dusun Caong, lokasi mata air terletak didaerah-daerah perbukitan dan tidak terlalu jauh dengan pemukiman masyarakat dimasing-masing dusun tersebut. Berdasarkan hasil pengamatan di lapangan masyarakat Desa Caong memanfaatkan sumber mata air ini sebagai pengairan lahan pertanian, budidaya ikan, merendam kayu dan bambu, keperluan rumah tangga MCK (mandi, cuci, kakus) dan konsumsi.

Mata air Desa Caong yang berada di Dusun Kayuara, Dusun Pelanjau, Dusun Pakan, Dan Dusun Caong memiliki kondisi yang masih terawat. Mata air ini debitnya besar, karena terletak di daerah perbukitan dan lokasinya lebih tinggi dari pemukiman masyarakat sehingga proses aliran air sangat cepat. Kondisi lingkungan yang berada di sekitar mata air masih sangat terjaga. Hal ini dapat dilihat dari kondisi hutan yang masih alami dan ditumbuhi pohon-pohon besar yang tetap menjaga kondisi sumber mata air tersebut. Schwab $d k k$ (1992) menyatakan fungsi vegetasi dalam hal ini pohon secara efektif dapat meningkatkan kemampuan tanah dalam mengabsorbsi air, mempertahankan atau meningkatkan laju infiltrasi. Manik (2012) menyatakan proses masuknya atau meresapnya air ke dalam tanah disebut infiltrasi.

Bentuk Kearifan Lokal Masyarakat Dalam Mengelola Sumber Mata Air
Sistem dalam tatanan kehidupan politik, sosial, ekonomi dan budaya, serta lingkungan yang hidup di tengahtengah masyarakat lokal dapat disebut kearifan lokal yang memiliki ciri yang bersifatnya dinamis, berkelanjutan dan dapat diterima oleh komunitasnya (Reza dan Hidayati, 2017). Pemahaman mengenai kearifan lokal tersebut memunculkan keingintahuan tentang kearifan lokal terkait dengan tatanan lingkungan yang dilakukan oleh masyarakat Desa Caong dalam pengelolaan sumber mata air. Kegiatan atau aktivitas yang dilakukan oleh masyarakat Desa Caong dalam pengelolaan mata air ini berupa kegiatan mengelola mata air serta tradisi dan ritual masyarakat, antara lain;

1. Kegiatan Pengelolaan Sumber Mata Air

Tindakan dalam menjaga mata air yang dilakukan oleh masyarakat yaitu tindakan pengelolaan mata air. Manik (2012) menyatakan pengelolaan didefinisikan sebagai upaya yang dilakukan manusia dalam pemanfaatan sumber daya alam dalam suatu wilayah sehingga dapat berfungsi untuk memenuhi kebutuhan hidup manusia. Kegiatan mengelola mata air antara lain;

\section{a) Membuat Bendungan Air (Pagunkg)}

Sebelum pengelolaan sumber mata air biasannya masyarakat membuat bendungan (Pagunkg) untuk menampung debit air yang mengalir sehingga memudahkan proses aliran air menuju pemukiman penduduk. Pada zaman dahulu proses pembuatan 
bendungan menggunakan batu dan ranting kayu sedangkan pipa saluran yang masih menggunakan tumbuhan bambu. Namun pada saat kemajuan teknologi sekarang ini proses pembuatan bendungan dengan cara modern yaitu menggunakan semen dan batu supaya kuat menampung aliran air tersebut. Air yang berada di bendungan tersebut selanjutnya dialirkan menggunakan pipa saluran, disetiap pemukiman biasannya di buat bak-bak penampungan air supaya memudahkan masyarakat dalam menggalirkan air disetiap rumah mereka, sehingga air yang menggalir bisa terbagi merata kesetiap rumah penduduk.

b) Gotong-Royong Membersihkan Lingkungan Sekitar Mata Air

Kegiatan yang dilakukan masyarakat adalah membersihkan lingkungan mata air yang dilakukan setiap satu bulan sekali dengan gotongroyong antar sesama masyarakat, kegiatan ini bertujuan supaya lingkungan sekitar mata air tersebut tetap terjaga tidak tertutupi tumbuhan liar dan dipenuhi dengan daun yang jatuh karena bisa menyumbat saringan pada bendungan. Kegiatan gotongroyong ini masih sering dilakukan oleh masyarakat khusunya masyarakat Desa Caong hal ini bertujuan untuk membangun jiwa sosial masyarakat supaya bisa saling bekerja sama dalam kegiatan yang bersifat membangun rasa persaudaraan antara sesama masyarakat tersebut. Selain itu masyarakat Desa Caong juga sering melakukan sosialisasi kepada masyarakat setempat untuk menerapkan budaya kearifan lokal yang mereka miliki kepada generasi muda yang bertujuan untuk melestarikan budaya yang sudah mereka jaga agar tidak hilang begitu saja akibat pengikisan teknologi pada saat sekarang ini.

c) Menanam Pohon Di Sekitar Lingkungan Mata Air

Masyarakat Desa Caong tidak hanya melakukan tindakan pengelolaan mata air saja akan tetapi masyarakat juga melakukan tindakan konservasi mata air. Menurut (Reza dan Hidayati. 2017) menjaga kuantitas dan kualitas sumber air untuk memenuhi kebutuhan mahkluk hidup dilakukan dengan upaya pemeliharaan keberadaan serta keberlanjutan keadaan, sifat, dan fungsi sumber daya air agar senantiasa tersedia baik pada waktu sekarang maupun yang akan datang. Tindakan yang masyarakat Desa Caong lakukan yaitu tidak menebang pohon sekitar mata air dan menanam pohon penghasil buah selain berfungsi dari segi ekologi juga berfungsi dari segi ekonomi masyarakat. Pohon yang masyarakat tanam berdasarkan pengetahuan yang masyarakat miliki yaitu pohon durian (Durio zubethinus), langsat (Lansium domesticum) dan manggis (Garcinia mangostana). Penanaman pohon ini biasanya dilakukan pada daerah yang rawan longsor seperti tebing-tebing yang berada di sekitar mata air tersebut. Tujuan dari penanaman pohon menurut masyarakat supaya bisa menjaga ketersediaan air di dalam tanah pada saat musim kemarau serta akar tanaman 
bisa menahan tanah pada saat musim hujan.

\section{d) Perbaikan Sarana}

Kegiatan perbaikan sarana dilakukan oleh masyarakat Desa Caong setiap akhir tahun. Kegiatan ini bertujuan untuk menjaga kelestarian fungsi sarana dan prasarana tersebut. Masyarakat yang menggunakan prasarana tersebut wajib untuk memelihara dan merawat prasarana yang telah dibangun supaya dapat digunakan dalam waktu yang lama. Perbaikan sarana biasannya dilakukan bersama-sama oleh masyarakat Desa Caong. Perbaikan sarana yang dilakukan biasanya mengganti pipa saluran air, memperbaiki bendungan air, dan memperbaiki penampungan air yang berada di setiap titik pemukiman penduduk.

\section{e) Membuat Saluran Air}

Dalam proses penyaluran air biasanya dilakukan dengan membuat saluran air supaya memudahkan air untuk mengalir ke pemukiman penduduk. Masyarakat Desa Caong menyalurkan air dengan cara membuat saluran air dimulai dari hulu mata air sampai ke hilir lingkungan pemukiman penduduk. Hal ini dilakukan supaya penyaluran air dapat terbagi merata di setiap rumah penduduk. Proses penyaluran air dilakukan dengan cara menyambungkan pipa-pipa air yang dipasang dari setiap bendungan yang dibuat, kemudian dialirkan ke bak penampungan air yang dibuat dari semen dengan bentuk persegi panjang, bak-bak penampungan ini dipasang dimasing-masing titik di daerah pemukiman penduduk, biasanya dalam satu dusun terdapat 3-4 bak penampungan air, air yang berada di dalam bak penampungan dialirkan ke setiap rumah penduduk yang berada di sekitar penampungan tersebut. Kegiatan ini dilakukan masyarakat Desa Caong dengan bersama-sama sehingga sumber mata air tersebut dapat di manfaatkan masyarakat baik untuk keperluan seharihari dan keperluan lainnya. Berdasarkan hasil penelitian yang sudah diuraikan diatas, bentuk pengelolaan sumber mata air di Desa Caong dapat diringkas seperti pada Tabel 1 .

Tabel 1. Bentuk Kegiatan Pengelolaan Mata Air (The Form of Water Source Management Activities)

\begin{tabular}{lll}
\hline No & \multicolumn{1}{c}{ Bentuk Kegiatan } & \multicolumn{1}{c}{ Fungsi } \\
\hline 1 & $\begin{array}{l}\text { Membuat } \\
\text { (Pagunkg) }\end{array}$ & \multicolumn{1}{c}{ Bendungan } \\
Gotong-royong Membersihkan & $\begin{array}{l}\text { Untuk menampung debit air dalam proses } \\
\text { pengaliran air }\end{array}$ & Untuk menjaga lingkungan sekitar mata air \\
& $\begin{array}{l}\text { Lingkungan Sekitar Mata Air } \\
\text { Menanam Pohon Disekitar }\end{array}$ & $\begin{array}{l}\text { Untuk menjaga ketersediaan air dan } \\
\text { menahan tanah }\end{array}$ \\
3 & $\begin{array}{l}\text { Lingkungan Mata Air } \\
\text { Perbaikan Sarana }\end{array}$ & $\begin{array}{l}\text { Untuk menjaga kelestarian fungsi sarana dan } \\
\text { prasarana } \\
\text { Untuk menyalurkan air ke pemukiman } \\
\text { penduduk }\end{array}$ \\
\hline
\end{tabular}


2. Kearifan Lokal Berupa Tradisi dan Ritual Masyarakat

\section{a) Hukum Adat}

Soepomo (1996) mengemukakan bahwa hukum adat adalah hukum tidak tertulis di dalam peraturan tidak tertulis, meliputi peraturan-peraturan hidup yang meskipun tidak ditetapkan oleh pemerintah tetapi ditaati dan didukung oleh rakyat berdasarkan atas keyakinan bahwasanya peraturan-peraturan tersebut mempunyai kekuatan hukum. Hukum adat yang berlaku dan diterapkan oleh masyarakat Desa Caong dalam menjaga dan mengelola sumber mata air antara lain hukum adat Tai tangah (hukum adat yang berlaku untuk pelangaran ringan), dan hukum adat enam Tai tangah (hukum adat yang berlaku untuk pelangaran berat). Hukum adat ini juga berlaku untuk semua aktivitas yang ada di Desa Caong tidak hanya dalam aktivitas menjaga dan mengelola sumber mata air. Hukum adat yang diberlakukan dalam menjaga dan mengelola sumber mata air jika seseorang dengan sengaja mengotori, merusak atau merambah hutan yang ada disekitar mata air baik yang berdampak besar dan maupun berdampak kecil bagi lingkungan sekitar mata air tersebut. Sanksi yang harus dibayar atau diterima seseorang jika melanggar disesuaikan dengan aturan yang sudah ditetapkan dari masing-masing hukum adat tersebut.

b) Norma

Norma dalam pengelolaan sumber mata air di Desa Caong terdapat dua pemahaman yaitu berupa aturan tertulis dan tidak tertulis, hampir semua masyarakat tidak paham terhadap aturan tertulis, dikarenakan memang belum ada aturan tertulis yang digunakan dalam pengelolaan sumber mata air sedangkan pemahaman terhadap aturan tertulis dikategorikan cukup paham sehingga dalam pengelolaan sumber mata air masyarakat mentaati normanorma yang tidak tertulis dalam pengelolaan sumber mata air tersebut. Berdasarkan hasil pengamatan di dapat walaupun tidak tertulis namun menjadi panduan untuk menetukan pola prilaku dari orang di dalam suatu masyarakat, yaitu prilaku-prilaku yang dinilai baik di masyarakat. Menurut Halim (2007) norma adalah segala peraturan baik tertulis maupun tidak tertulis yang pada intinya merupakan suatu peraturan yang berlaku sebagai acuan atau pedoman yang harus ditaati oleh setiap individu dalam masyarakat. Bentuk-bentuk pelanggaran yang sering ditemui yang melanggar norma masyarakat Desa Caong dalam aktivitas mengelola sumber mata air yaitu membuang sampah di sekitar lingkungan mata air, merusak hutan dilingkungan mata air, dan mengotori sumber mata air, tidak semua masyarakat Desa Caong melakukan pelanggaran tersebut pelanggaran ini hanya pernah dilakukan oleh beberapa individu saja.

c) Aturan-aturan Khusus

Aturan-aturan khusus yang dibuat masyarakat Desa Caong adalah sebagai aturan tambahan yang ditetapkan khusus untuk masyarakat yang berada diluar dan di dalam lingkungan Desa 
Caong. Aturan-aturan khusus yang berada di Desa Caong lebih mengacu ke lingkungan hutan sekitar mata air misalnya dalam menjaga lingkungan sumber mata air tersebut. Aturan-aturan tersebut berupa larangan menebang pohon, merambah hutan, mebuat perkebunan, dan mengotori lingkungan sekitar mata air tersebut, dan jika ada yang melanggar aturan tersebut akan diberikan sanksi sesuai peraturan yang berlaku.

d) Ritual Adat Sembahyang di Mata Air (Nyangahant'n ka ulu ai)

Ritual adat yang ada di Desa Caong antara lain sembahyang di mata air (Nyangahant'n ka ulu ai), yaitu ritual yang dilakukan masyarakat Desa Caong sebelum melakukan kegiatan pengelolaan sumber mata air atau membersihkan lingkungan sekitar mata air yang akan digunakan masyarakat

Tabel 2. Bentuk Tradisi dan Ritual Masyarakat (Tradition and Ritual of Local Community)

\begin{tabular}{|c|c|c|}
\hline No & Tradisi dan Ritual Masyarakat & Fungsi \\
\hline 1 & Hukum Adat & $\begin{array}{l}\text { Untuk mengatur aktivitas dalam menjaga dan } \\
\text { mengelola sumber mata air }\end{array}$ \\
\hline 2 & Norma & $\begin{array}{l}\text { Untuk menjaga prilaku dan etika masyarakat } \\
\text { dalam aktivitas mengelola mata air }\end{array}$ \\
\hline 3 & Aturan-aturan Khusus & $\begin{array}{l}\text { Untuk menjaga lingkungan sekitar mata air agar } \\
\text { tidak rusak dan tetap terjaga }\end{array}$ \\
\hline 4 & $\begin{array}{l}\text { Ritual Adat Sembahyang di Mata Air } \\
\text { (Nyangahant'n ka ulu ai) }\end{array}$ & $\begin{array}{l}\text { Untuk meminta izin kepada tuhan dalam } \\
\text { pengelolaan dan pemanfaatan sumber mata air } \\
\text { supaya diberkati dan diberi rezeki yang } \\
\text { melimpah. }\end{array}$ \\
\hline
\end{tabular}

Frekuensi Responden Berdasarkan

Tingkat Variabel

Frekuensi Tingkat Persepsi dengan memberikan sesajian dan persembahan yang berupa ayam kampung, tumpi (cucur), bontok'ng (beras yang dilipat dengan daun dan dimasak dengan bambu), poe (pulut yang dimasak dalam bambu), dan lain sebagainya. Tujuan ritual ini adalah untuk meminta izin kepada Jubata (tuhan) supaya apa yang mereka ambil dari alam dan manfaatkan bisa di berkati dan memberikan rezeki yang melimpah dalam pemanfaatannya. Ritual adat ini biasanya diadakan setiap satu tahun sekali yaitu pada setiap bulan april yang berkenaan dengan upacara pesta panen (gawai). Berdasarkan hasil penelitian yang sudah diuraikan diatas, bentuk kearifan lokal berupa tradisi dan ritual masyarakat dalam pengelolaan sumber mata air di Desa Caong dapat diringkas seperti pada Tabel 2. 
Tabel 3. Frekuensi Tingkat Persepsi (Frequency of Perception Level)

\begin{tabular}{clcc}
\hline No & Kearifan Lokal & Frekuensi & Presentase (\%) \\
\hline 1. & Positif & 39 & 45.88 \\
2. & Netral & 27 & 31.76 \\
3. & Negatif & 19 & 22.35 \\
\hline
\end{tabular}

Sumber : Hasil Analisis Data Primer Penelitian Di Desa Caong 2019

Berdasarkan Tabel 3 menunjukan bahwa frekuensi tingkat persepsi masyarakat di Desa Caong Kecamatan Mempawah Hulu Kabupaten Landak terhadap pengelolaan sumber mata air dengan kategori positif sebanyak 39 responden $(45,88 \%)$, kategori netral sebanyak 27 responden $(31,76 \%)$, dan kategori negatif sebanyak 19 responden $(22,35 \%)$. Berdasarkan pengamatan yang telah dilakukan, masyarakat yang mempunyai persepsi positif adalah masyarakat yang telah memahami dirinya dengan baik bahwa dirinya hidup tergantung dari sumber daya alam dan menginginkan agar sumberdaya tersebut dikelola secara lestari. Hal ini menunjukan bahwa masyarakat telah merasakan secara langsung maupun tidak langsung manfaat dari keberadaan sumber mata air tersebut. Beberapa manfaat yang masyarakat rasakan dalam kehidupan sehari-hari yakni untuk keperluan rumah tangga seperti MCK (Mandi, Cuci, Kakus), konsumsi, budidaya ikan, budidaya pertanian padi sawah, dan sebagainya, terlebih untuk masyarakat yang memang pekerjaan utamanya adalah petani, akan sangat merasakan banyak manfaat sumber daya air tersebut. Masyarakat tersebut juga mempunyai kesadaran bahwa dengan terus menjaga dan melestarikan sumber mata air sama dengan menjaga kelangsungan hidup dan masa depan orang banyak.

\section{Frekuensi Tingkat Hukum Adat}

Kategori berdasarkan hukum adat dalam penelitian ini dikelompokan menjadi tiga yakni tinggi, sedang, rendah. Frekuensi hukum adat dapat dilihat pada Tabel 4.

Tabel 4. Frekuensi Tingkat Hukum Adat (Customary Legal Level Frequency)

\begin{tabular}{clcc}
\hline No & Kearifan Lokal & Frekuensi & Presentase (\%) \\
\hline 1. & Tinggi & 36 & 42.35 \\
2. & Sedang & 24 & 28.24 \\
3. & Rendah & 25 & 29.41 \\
\hline & & 85 & 100 \\
\hline
\end{tabular}

Sumber : Hasil Analisis Data Primer Penelitian Di Desa Caong 2019

Berdasarkan Tabel 4 diperoleh kategori frekuensi hukum adat masyarakat Desa Caong Kecamatan Mempawah Hulu Kabupaten Landak dengan kategori tinggi sebanyak 36 responden $(42,35 \%)$, kategori sedang sebanyak 24 responden $(28,24 \%)$ dan kategori rendah sebanyak 25 responden $(29,41 \%)$. Hal ini menunjukan bahwa dari 85 responden penelitian diperoleh 
tingkat hukum adat terbanyak dengan kategori tinggi. Berdasarkan pengamatan tingkat hukum adat yang tinggi tersebut disebabkan karena sebagian besar masyarakat yang ada di Desa Caong masih menerapkan dan mematuhi hukum adat tersebut, masyarakat mempercayai bahwa dengan adanya hukum adat yang berlaku di desa mereka baik dalam kegiatan pengelolaan sumber mata air maupun kegiatan lainnya dapat memberikan pengaruh yang positif terhadap tindakan dan prilaku masyarakat tersebut sehingga ketentraman dan keamanan di sekitar masyarakat baik alam dan lingkungannya dapat terjaga dengan baik.

\section{Frekuensi Tingkat Kepercayaan}

Frekuensi tingkat kepercayaan masyarakat dalam mengelola sumber mata air dapat dilihat pada Tabel 5.

Tabel 5. Frekuensi Tingkat Kepercayaan (Confidence Level Frequency)

\begin{tabular}{clcc}
\hline No & Kearifan Lokal & Frekuensi & Presentase (\%) \\
\hline 1. & Tinggi & 31 & 36.47 \\
2. & Sedang & 30 & 35.29 \\
3. & Rendah & 24 & 28.24 \\
\hline
\end{tabular}

Sumber : Hasil Analisis Data Primer Penelitian Di Desa Caong 2019

Tabel 5 menunjukan bahwa sebanyak 31 responden $(36,47 \%)$ mempunyai tingkat kepercayaan tinggi dalam kegiatan mengelola sumber mata air, 30 responden $(35,29 \%)$ mempunyai tingkat kepercayaan sedang dalam kegiatan mengelola sumber mata air, dan 24 responden $(28,24 \%)$ mempunyai tingkat kepercayaan rendah dalam kegiatan mengelola sumber mata air. Hal ini dikarenakan sebagian besar masyarakat Desa Caong masih memiliki hubungan sosial yang tinggi hampir setiap kegiatan yang ada di Desa Caong baik itu kegiatan dalam pengelolaan sumber mata air dan kegiatan yang membangun rasa persaudaraan dan kekeluargaan masih kental dalam masyarakat Desa Caong. Masyarakat berpendapat bahwa dengan adanya kebersamaan sesuatu yang sulit dikerjakan sendiri akan lebih mudah jika dilakukan bersama-sama. Selaras dengan ungkapan Fukuyama (2001) bahwa kepercayaan ibarat pelumas yang membuat jalannya kelompok atau organisasi menjadi lebih efisien. Kepercayaan antar sesama masyarakat dalam kegiatan menjaga dan mengelola sumber mata air sangat penting untuk keberlanjutan sumber mata air tersebut sehingga bisa terjalin hubungan yang positif diantara masyarakat dalam melakukan aktivitas mengelola dan menjaga sumber mata air.

\section{Frekuensi Tingkat Pengetahuan}

Frekuensi pengetahuan responden terhadap pengelolaan sumber mata air dapat dilihat pada Tabel 6. 
Tabel 6. Frekuensi Tingkat Pengetahuan (Knowledge Rate Frequency)

\begin{tabular}{clcc}
\hline No & Kearifan Lokal & Frekuensi & Presentase (\%) \\
\hline 1. & Tinggi & 38 & 44.71 \\
2. & Sedang & 19 & 22.35 \\
3. & Rendah & 28 & 32.94 \\
\hline
\end{tabular}

Sumber : Hasil Analisis Data Primer Penelitian Di Desa Caong 2019

Berdasarkan Tabel 6 diperoleh kategori tinggi sebanyak 38 responden (44,71\%), sedang sebanyak 19 responden $(22,35 \%)$, dan rendah sebanyak 28 responden $(32,94 \%)$. Dengan demikian dapat disimpulkan bahwa dari 85 responden penelitian diperoleh tingkat pengetahuan terbanyak dengan kategori tinggi. Notoatmodjo (2010), mengatakan bahwa semakin tinggi tingkat pengetahuan seseorang maka semakin tinggi pula kemampuan individu tersebut dalam melakukan penilaian terhadap suatu materi atau objek. Berdasarkan hasil pengamatan yang di peroleh di lapangan masyarakat tidak hanya mengandalkan pengetahuan Tabel 7. Uji Statistik Deskriptif Chi Square (Test Descriptive Statistical Chi Square)

\begin{tabular}{ccccccc}
\hline No & Alternatif Pilihan & $f_{0}$ & $f_{h}$ & $\left(f_{0-} f_{h}\right)$ & $\left(f_{0-} f_{h}\right)^{2}$ & $\left(\frac{f_{0-} f_{h}}{f h}\right)^{2}$ \\
\hline 1 & Positif & 39 & 28 & 11 & 121 & 4.32 \\
2 & Netral & 27 & 28 & -1 & 2 & 0.07 \\
3 & Negatif & 19 & 28 & -9 & 81 & 2.89 \\
\hline & Jumlah & 85 & 85 & 1 & & 7.28 \\
\hline
\end{tabular}

Sumber : Hasil Analisis Data Primer Penelitian Di Desa Caong 2019

Hasil uji statistik deskriptif (Uji Chi Square) diperoleh nilai Chi Square (r) pada taraf kepercayaan 5\% sebesar 7,28 dan nilai Chi Square Tabel sebesar 5,99 ( $\mathrm{r}$ hitung > $\mathrm{r}$ tabel). Berdasarkan uji statistik deskriptif dapat disimpulkan bahwa terdapat perbedaan yang signifikan frekuensi persepsi tradisional yang mereka miliki tetapi mereka juga mendapatkan pengetahuan dari berbagai sumber seperti penyuluhan atau sosialisasi dari instansi terkait mengenai pengolahan sumber daya alam, pemanfaatan dan fungsinya sehingga tingkat pengetahuan masyarakat terhadap pengelolaan sumberdaya air di Desa Caong berada pada kategori tinggi.

\section{Analisis Deskriptif}

Analisis deskriptif kearifan lokal dilakukan dengan analisis non parametrik Uji chi square untuk melihat tingkat kearifan lokal masyarakat dalam mengelola sumber mata air disajikan pada Tabel 7. 
dan hasil uji statistik deskriptif dapat diinterprestasi bahwa dari 85 responden penelitian sebagian besar $(45,88 \%)$ cenderung memiliki tingkat persepsi masyarakat positif terhadap pengelolaan sumber mata air di Desa Caong disebabkan karena pada dasarnya masyarakat memiliki tujuan bersama untuk tetap menjaga dan melestarikan budaya mereka dalam kegiatan pengelolaan sumber mata air agar tidak hilang dan tetap diterapkan kepada setiap generasi mereka pada masa yang akan datang. Masyarakat Desa Caong juga menyadari bahwa ketergantungan akan adanya sumber daya air sangat tinggi guna untuk memenuhi kebutuhan hidup mereka sehingga mereka memberikan tanggapan yang positif terhadap budaya kearifan lokal tersebut, namun tidak semua masyarakat memahami kalau sumber daya tersebut perlu dijaga dan dikelola dengan lestari agar manfaatnya bisa diperoleh secara berkelanjutan.

\section{Analisis Inferensial}

Menganalisis variabel terikat dan variabel bebas dilakukan dengan korelasi Kendall Tau yang terdiri dari 1 (satu) variabel terikat yaitu kearifan lokal dan 4 (empat) variabel bebas yaitu hukum adat, tingkat kepercayaan, tingkat pengetahuan, dan tingkat persepsi. Hasil uji korelasi variabel terikat dengan variabel bebas dapat dilihat pada Tabel 8 .

Tabel 8. Hasil Uji Statistik Korelasi Kendall Tau Hubungan Variabel Terikat Dengan Variabel Bebas (Statistical Test Result Correlation Kendall Tau Variable Relationships Tied To Free Variables)

\section{Persepsi (Y)}

\begin{tabular}{|c|c|c|c|c|c|}
\hline No & Variabel bebas & $\mathbf{N}$ & Correlatio & Sig & Keterangan \\
\hline & & & Coeffisient & (2-Tailed) & \\
\hline 1 & Hukum adat & 85 & 1.000 & 0.001 & Signifikan \\
\hline 2 & Kepercayaan & 85 & 0.429 & 0.000 & Signifikan \\
\hline 3 & Pengetahuan & 85 & 0.754 & 0.000 & Signifikan \\
\hline
\end{tabular}

Sumber : Hasil Analisis Data Primer Penelitian Di Desa Caong 2019

1. Hubungan Persepsi Masyarakat dengan Hukum Adat

Hasil uji statistik korelasi Kendall Tau antara persepsi masyarakat dalam menerapkan kearifan lokal terhadap pengelolaan sumber mata air di Desa Caong dengan hukum adat diperoleh nilai Sig.(2-tailed) 0,001 lebih kecil dari taraf signifikan 5\% atau nilai Sig 0,001 $<0,05$ dengan nilai koefisien korelasi positif 1,000. Hal ini menunjukan bahwa terdapat hubungan yang positif signifikan antara persepsi masyarakat dalam menerapkan kearifan lokal terhadap pengelolaan sumber mata air Desa Caong dengan hukum adat masyarakat (Ha diterima Ho ditolak). Nilai koefisien korelasi positif menunjukan bahwa semakin positif atau tinggi hukum adat yang berlaku di masyarakat, maka persepsi masyarakat terhadap kearifan lokal dalam 
pengelolaan sumber mata air di Desa Caong akan cenderung positif. Menurut Rukka (2013) dalam penelitiannya menjelaskan bahwa kearifan lokal adalah kesadaran hukum manusia dimana dia berada, karena kearifan lokal lahir sebagai bagian dari kebudayaan dan manisfestasi atas cita, cipta dan karsa manusia, oleh karena itu dia hidup di masyarakat. Masyarakat berpendapat bahwa hukum adat sangat membantu dalam menjaga keamanan dan ketertiban lingkungan, contohnya dalam menjaga lingkungan sekitar sumber mata air. Soepomo (1996) mengemukakan bahwa hukum adat adalah hukum tidak tertulis di dalam peraturan tidak tertulis, meliputi peraturan-peraturan hidup yang meskipun tidak ditetapkan oleh pemerintah tetapi ditaati dan didukung oleh rakyat berdasarkan atas keyakinan bahwasanya peraturan-peraturan tersebut mempunyai kekuatan hukum.

2. Hubungan Persepsi Masyarakat dengan Tingkat Kepercayaan

Hasil uji statistik korelasi Kendall Tau antara persepsi masyarakat terhadap pengelolaan sumber mata air di Desa Caong dengan tingkat kepercayaan masyarakat diperoleh nilai Sig.(2-tailed) 0,000 lebih kecil dari taraf signifikan 5\% atau nilai Sig $0,000<$ 0,05 dengan nilai koefisien korelasi positif 0,429. Hal ini menunjukan bahwa terdapat hubungan yang positif signifikan antara persepsi masyarakat terhadap pengelolaan sumber mata air Desa Caong dengan tingkat kepercayaan masyarakat (Ha diterima
Ho ditolak). Nilai koefisien korelasi positif menunjukan bahwa semakin positif atau tinggi tingkat kepercayaan masyarakat, maka persepsi masyarakat terhadap kearifan lokal dalam pengelolaan sumber mata air di Desa Caong akan cenderung positif. Berdasarkan hasil pengamatan diketahui bahwa tingkat kepercayaan masyarakat terhadap pengelolaan sumber mata air Desa Caong sebagian besar $(36,47 \%)$ cenderung tinggi. Sedangkan persepsi masyarakat terhadap pengelolaan sumber mata air di Desa Caong sebagian besar $(45,88 \%)$ cenderung positif. Hal ini disebabkan karena masyarakat Desa Caong masih memiliki hubungan sosial yang tinggi hampir setiap kegiatan yang ada di Desa Caong baik itu kegiatan mengelola sumber mata air dan kegiatan yang membangun rasa persaudaraan dan kekeluargaan masih kental dalam masyarakat Desa Caong. Masyarakat berpendapat bahwa dengan adanya kebersamaan sesuatu yang sulit dikerjakan sendiri akan lebih mudah jika dilakukan bersama sama dengan saling percaya dan saling mendukung satu sama lain.

3. Hubungan Persepsi Masyarakat dengan Tingkat Pengetahuan

Hasil uji statistik korelasi Kendall Tau antara persepsi masyarakat terhadap pengelolaan sumber mata air di Desa Caong dengan tingkat pengetahuan masyarakat diperoleh nilai Sig.(2-tailed) 0,000 lebih kecil dari taraf signifikan 5\% atau nilai Sig 0,000 < 0,05 dengan nilai koefisien korelasi positif 0,754 . Hal ini menujukan bahwa 
terdapat hubungan yang positif signifikan antara persepsi masyarakat terhadap pengelolaan sumber mata air Desa Caong dengan tingkat pengetahuan masyarakat (Ha diterima Ho ditolak). Nilai koefisien korelasi positif menunjukan bahwa semakin positif atau tinggi tingkat pengetahuan masyarakat, maka persepsi masyarakat terhadap aktivitas kearifan lokal dalam pengelolaan sumber mata air di Desa Caong akan cenderung positif. Menurut Alpian (2009) pengetahuan adalah segala sesuatu yang diketahui, kepandaian, karena mempelajari dan mengalami. Berdasarkan hasil pengamatan diketahui bahwa tingkat pengetahuan masyarakat terhadap pengelolaan sumber mata air di Desa Caong sebagian besar $(44,71 \%)$ cenderung tinggi. Sedangkan persepsi masyarakat terhadap pengelolaan sumber mata air di Desa Caong sebagian besar $(45,88 \%)$ cenderung positif. Bina (2006) menyatakan bahwa pengetahuan hasil dari tahu dan ini terjadi setelah melakukan penginderaan terhadap objek tertentu. Pengetahuan masyarakat tentang pengelolaan sumber mata air serta manfaatnya dan upayaupaya yang harus dilakukan untuk menjaga dan melestarikan sumber mata air sangat tinggi dan masyarakat sangat merasakan manfaat yang di dapatkan melalui kearifan lokal dalam mengelola sumber mata air tersebut. Pengetahuan mengenai pengelolaan sumber mata air sangat penting karena merupakan gambaran mengenai popularitas lokasi oleh masyarakat yang juga menunjukan adanya keterkaitan antara masyarakat dengan pengelolaan dan pelestarian sumber daya air. Pengetahuan lokal yang ada pada masyarakat terhadap pengelolaan sumber mata air harus tetap dijaga demi kelestarian sumber mata air tersebut dengan memberikan pengetahuan berupa penyuluhan dan pelatihan kepada generasi muda sehingga pengetahuan lokal yang dimiliki tidak hilang begitu saja dan bisa menjaga keberlanjutan pengelolaan sumber mata air dimasa yang akan datang.

\section{Kesimpulan}

1. Bentuk-bentuk kearifan lokal masyarakat dalam mengelola sumber mata air di Desa Caong Kecamatan Mempawah Hulu Kabupaten Landak yaitu meliputi: kegiatan mengelola mata air dan tradisi dan ritual masyarakat: kegiatan mengelola mata air ( membuat bendungan (Pagunkg), gotong royong membersihkan mata air yang dilakukan setiap satu bulan sekali, menanam pohon, perbaikan sarana, dan membuat saluran air. Sedangakan tradisi dan ritual masyarakat yang berhubungan dengan pengelolaan sumber mata air antara lain: (Hukum adat, norma, aturan-aturan khusus, dan ritual adat (ritual adat seperti sembahayang di mata air (Nyangahan't ka ulu ai)).

2. Terdapat hubungan yang positif signifikan antara persepsi masyarakat dalam menerapkan kearifan lokal terhadap pengelolaan sumber mata air di Desa Caong 
Kecamatan Mempawah Hulu Kabupaten Landak dengan hukum adat, tingkat kepercayaan, dan tingkat pengetahuan.

\section{Saran}

1. Adanya tingkat kearifan lokal tinggi dari masyarakat terhadap pengelolaan mata air, hendaknya di arahkan agar berwujud pada prilaku, sikap dan kesadaran masyarakat yang arif lingkungan, maka diperlukan pembinaan secara rutin, dengan penyuluhan, pertemuanpertemuan, dan diskusi. Keberhasilan kearifan lokal dalam mengelola sumber mata air, masih dalam artian fisik apa adanya, belum pada mempertahankan debit airnya, diperlukan pengelolaan hutan disekitar mata airnya, dengan adanya penanaman dan pemeliharaan. Selain itu masyarakat sekitar harus berpartisipasi dalam menjaga lingkungan sekitar mata air, dan tidak merusak hutan seperti menebang dan membuka lahan perkebunan di sekitar mata air.

UCAPAN TERIMAKASIH

Penulis mengucapkan terimakasih kepada masyarakat Desa Caong Kecamatan Mempawah Hulu Kabupaten Landak yang telah mengizinkan untuk melakukan penelitian di Desa tersebut dan telah memberikan respon yang sangat baik serta bersedia memberikan informasi dan ilmu yang berkaitan dengan penelitian sehingga penelitian ini berjalan dengan lancar tanpa suatu kendala apapun.

\section{DAFTAR PUSTAKA}

Akhmar AM dan Syarifuddin, 2007. Mengungkap Kearifan

Lingkungan Sulawesi Selatan, PPLH Regional Sulawesi, Maluku dan Papua. Makasar: Kementrian Negara Lingkungan Hidup RI dan Masagena Press.

Buwono N, Muda G dan Arsad S. 2017. Pngelolaan mata air sumberawan berbasis masyarakat di desa toyomarto kecamatan singosari kabupaten malang. $J$. Perikanan dan Kelautan. 9(1): 25-36.

Bina K, Lestantyo D, Murtiningsih D. 2006. Hubungan Karakteristik Pekerja Dengan Praktik Penerapan Prosedur Keselamatan Kerja di PT. Bina Buna Kimia Ungaran. Fkm. Undip. Jurnal promosi kesehatan indonesia. Vol.1. No. 2. Diakses 17 April 2018 .

Fukuyama, F. 2001. Sosial Capital, Civil Society, and development. Third Word Quarterly, 22:7-200.

Khadapi H. 2015. Persepsi Masyarakat Desa Sungai Awan Kanan Terhadap Keberadaan Hutan Mangrove Di Kawasan Pantai Air Mata Permai Kabupaten Ketapang. Jurnal Hutan Lestari. 1(4): 108 - 116.

Manik K dan Sontang E. 2009. Pengelolaan Lingkungan Hidup. Jakarta: Djambatan.

Manik K. 2012. Pengelolaan Daerah Aliran Sungai Dan Konservasi Tanah Sebagai Basis Pembangunan Berkelanjutan. Buku. Universitas Lampung. 
Bandar

Lampung. $87 \mathrm{hlm}$.

Notoatmodjo S. 2010. Metodologi Penelitian Kesehatan. Jakarta : Rineka Cipta.

Oktaviani T, dan Dharmawan A $\mathrm{H}$. 2010. Kearifan Lokal Dalam Pengelolaan Sumberdaya Air Di Kampung Kuta. J. Transdisiplin Sosiologi, Komunikasi, dan Ekologi Manusia. 4(3): 345-355.

Priyatno D. 2010. Belajar Cepat Olah Data Statistik dengan SPSS. Yogyakarta : Andi.

Reza M dan Hidayanti A. 2017. Kearifan Lokal Suku Sasak dalam Pengelolaan Sumberdaya Air Desa Lenek Daya Kecamatan Aikmel Kabupaten Lombok Timur. J. PWK Fakultas Teknik Sipil dan Perencanaan ITN. 30(15): 1-14.

Rukka S. 2013. Kearifan Lokal dan Kesadaran Hukum. 13(1) : 173186.

Schwab GO, Fangmeir D D, Elliot W J, and Frevert R K. 1992. Soil ang Water Conservation Engineering. Four Edition, John Wiley \& Sons. Inc, New York. 528 hlm.

Soepomo R. 1996. Bab-bab Tentang Hukum Adat. Jakarta: Universitas Jakarta. 